\title{
Barriers to innovation in building and construction
}

\author{
T.L. Webb \\ School of Business Leadership, University of South Africa
}

\begin{abstract}
Innovation in the building and construction industries is frequently prevented or inhibited by conservatism, selfrighteousness, prescriptions, laziness, excessive caution or fear of higher costs. Such barriers to innovation have reduced efficiency and productivity, adversely affected the performance of buildings and other structures, increased costs and resulted in the waste of energy, materials and water. The effective, timeous and economic application of innovations can be achieved within organizations by better management, by encouraging research and development, the procurement and evaluation of innovation, personnel training and monitoring or feedback. Also important in a broader context are better education and training for all concerned with the potential, limitations, selection and implementation of innovation; im. proved communication in-house, between disciplines and with research agencies; updated and realistic legislation such as regulations, and meaningful research and development.

S. Afr. J. Bus. Mgmt. 1981, 12: $95-98$
\end{abstract}

Innovasie in die bou- en konstruksiebedryf word dikwels deur konserwatisme, selfvoldaanheid, voorskrifte, luiheid, oordrewe versigtigheid of vrees vir hoër koste geïnhibeer of verhinder. Sulke faktore wat innovasie terughou het werkverrigting en produktiwiteit verminder, die doeltreffendheid van geboue en ander strukture nadelig beïnvloed, koste laat toeneem en het gelei tot die vermorsing van energie, materiaal en water. Binne ondernemings kan die doeltreffende, tydige en ekonomiese benutting van innovasies bereik word deur beter bestuur, deur die aanmoediging van navorsing en ontwikkeling, die verkryging en evaluering van innovasies, personeelopleiding en opvolging en terugvoering. In breër verband is ook belangrik beter onderwys en opleiding vir almal betrokke by die potensiaal, beperkings, seleksie en implementering van innovasie; verbeterde kommunikasie binne maatskappye, tussen dissiplines en met navorsingsorganisasies; die gereelde bywerk van wetgewing soos bouregulasies; en betekenisvolle navorsing en ontwikkeling.

S. Afr. Tydskr. Bedryfsl. 1981, 12: $95-98$

Paper at 'The way ahead' conference of the SA Institute of Civil Engineers, Johannesburg, June $15-16,1981$.

T.L. Webb

Professor, School of Business Leadership, University of South Africa. P.O. Box 392, Pretoria 0001, RSA

Accepted July 198

\section{Introduction}

All people concerned with building and construction are aware of the traditional and in a sense notorious resistance to innovation and change in the building and construction industries. While there are good reasons for this, it is most unfortunate because it means that both technical and managerial improvements are not applied either as rapidly or as effectively as they could be. This has serious adverse consequences on the economics, quality and speed of building and construction.

The purpose of this paper is to review, essentially in general terms, the nature of and the reasons for this resistance to innovation, its consequences and then to outline possible ways and means of overcoming them.

\section{Nature of and reasons for resistance to innovation}

Resistance to innovation manifests itself in many forms, sometimes interrelated.

In its simplest form the 'What was good enough for Grandpa is good enough for me' closed mind syndrome is a kind of dogged conviction that anything new or different is in principle bound to be less satisfactory than the familiar. A second form is the 'I know what is best' psychosis, generally a dictatorial and assertive, and sometimes even sadistic, cover-up for a lack of knowledge or an inferiority complex, characteristic of aggressive people with a complete lack of imagination and who have not bothered to keep up with events. A third variation is the 'Its-in-the-book-so-do-it-that-way' kind of bureaucratic tunnel vision which characterizes the person who wants to cover himself at all costs and at all times. A fourth posture is the ' 1 -can't-be-bothered-to-do-it' attitude, common among lazy slipshod people who just don't have the initiative or mental energy to consider alternatives. The fifth superstition is the 'for-Pete's-sake-don't-takea-chance' misconception, often a result of incompetence or a lack of knowledge, or of technological myopia. Lastly, we have the 'It's cheaper this way' affectation, often based on the quite sincere belief that any different approach might cost more, but in reality because the real costs of the alternatives have not been looked at closely enough.

All of these can apply to the designer, the contractor, the supervisor or the inspector. They are unrelated to age and experience or seniority or the nature of a man's responsibilities, and while generally a consequence of a 
lack of knowledge, understanding, maturity, interest or vision on the part of a person, they are sometimes just the result of the system.

More specifically in the context of the building and construction industries the reasons for resistance to innovation are:

(a) The fact that the building and construction industries, particularly the former, are very fragmented, consisting of a large number of sub-sections which are functionally largely independent but technologically interdependent. No clear and consistent communication channels exist since no single person has real and overriding authority over the design and building process. For instance in a typical building project a chain of no less than 14, and sometimes more, professional, industrial, public and labour agencies are involved. Each of these plays a significant but seldom clearly defined role in the design and construction process, but must nevertheless take decisions in different fields, at different levels and at different times, sometimes more than once. Along this line there are inevitably several people who fall into one of the six 'resistant' categories mentioned and the nett effect is therefore to inhibit rather than encourage innovation.

(b) The whole building community has (and for very good reasons, in that mistakes or failures are very expensive and may have adverse effects on health and safety) long established conservative traditions and is thus, by experience as it were, resistant to innovation.

(c) Outmoded or otherwise unsatisfactory building regulations, specifications and other documentation frequently hamper the smooth and rapid application of new knowledge because they may be unduly restrictive owing to obsolescence and/or inflexibility both in drafting them and in interpreting and applying them. Here the lack of knowledge of innovations and the unstandable belt-and-brace approach of building inspectors and other officials concerned with building legislation are serious barriers. The concept of national and as far as possible uniform building regulations has a great deal in its favour, and is indeed overdue in South Africa since today so many designers and contractors operate on a national rather than a regional basis. However, some reservations must be expressed regarding the recently gazetted draft national building regulations in that certain requirements, the fact that they are essentially prescriptive rather than performancebased and are in parts somewhat vague, may well result in their rigid implementation seriously inhibiting innovation.

(d) The fact that each building project is almost unique in terms of design, foundation conditions, labour and above all personalities, means that a highly complex one-off situation exists. This makes implementation of innovative developments a very much more complex and difficult matter than for instance in more standardized or assembly-line type operations. (e) Parodoxically, economic factors may hinder rather than promote the effective, immediate and widespread application of innovation. For instance the apparently high cost of research and development, and the fact that many building and some construction firms are too small or do not have the necessary technical expertise to apply new developments, often inhibit their use. Also in such firms the lack of capital and the uncertainty as to its validity may prevent the use of a new technique or material.

(f) A basic communication problem often exists between research personnel and many persons in the industry or the professions in that the former may have difficulty in appreciating the practical problems in building, and the builder or practitioner may not fully appreciate the complexity or potential of an innovation.

(g) During times of high building or construction activity it often happens that those responsible for design and construction are so fully occupied that they simply do not have the time to acquaint themselves with new developments. Even worse is the situation when the application of an innovation is attempted and either because the staff are not sufficiently trained or because designers have not had the time to ensure that it is properly studied, it turns out to be a dismal failure.

(h) In the field of innovative management a special and almost chronic problem is the intrinsic resistance to a new management policy or technique - often coupled with suspicion. Perhaps this is because in the building and construction industry long established and close personal relations are a very basic feature of management, and anything new or radically different is resented and can easily lead to confusion and misunderstandings.

(i) As far as contractual procedures are concerned (and if any field is in need of a new approach, this is it) innovation is almost pathologically resisted. The basic reason here is probably the fact that this is, perhaps sometimes erroneously, seen to be the area of competition or where profits are made or lost, and which is also sensitive to irregularities. An important factor here too is the traditionally almost confrontational attitude between contractor and client, notably in the public sector. Regrettably the building industry is all too often seen as being noisy, undependable, somewhat disreputable and always prepared to turn a quick buck, while the contractor may tend to view the client as a sharp fellow, out to get his pound of flesh and more than prepared to grind the poor honest contractor into the ground. Obviously these are exaggerated views, but there is probably enough truth in them to justify action to remove the reasons.

(j) In the field of manpower utilization a reason for resistance to inevitable changes is often prejudice. One example of particular importance in South Africa has been the antipathy to the rational and logical use of black skilled labour - a remarkable thing about this has been its persistence, and intensity, often by those who were not directly concerned. Another remarkable feature about it and a gratifying one, is 
the smoothness with which it is now being accepted by everyone. Only slightly more understandable are the traditional 'chalk line' type barriers between trades, so much a feature of traditional trade union attitudes, mercifully less common in this country, but still a serious problem in many overseas countries.

\section{Consequences of resistance to innovation}

The consequences of technological and managerial advances not being effectively applied are numerous and serious. Because it is in the nature of the beast, and is impossible to quantify or even assess with any accuracy the effects of something which has not happened, the adverse results are generally underestimated and often unappreciated simply because we have no yardstick with which to measure them. It is therefore instructive to consider some of these consequences qualitatively.

There is no doubt that, whatever the reason might be, the fact that modern technology and management are not effectively implemented, has materially reduced the efficiency and productivity of building and construction. Many more could be given but just two striking examples are the long delay which occurred before tower cranes were widely used and the present time-consuming approval procedures before a township can be built.

Similarly the technical performance of many buildings and other structures has been adversely affected by the fact that new advances have not been applied either as early or as effectively as the available knowledge could have permitted. Again only two of many examples. One is that if existing know-how in respect of environmental engineering had been applied to large tall buildings, the thermal performance and economics of many of our glass-clad cereal-box-on-end-buildings could have been substantially enhanced. Another is that if available knowledge and procedures for the prevention of damage to buildings caused by heaving or expansive soils had been effectively utilized, a great deal of damage and abortive expenditure could have been avoided.

In a time when escalating building and construction costs are a profound and growing cause for concern, it is sad to have to say that had existing and proven techniques of predetermining and controlling costs been strictly and objectively applied, the country could have been saved many more millions of rand. Furthermore, the present unrealistically and indefensibly high aspirations of so many people and agencies in respect of buildings, notably housing for the middle and upper income groups and some public buildings, would not have reached the comic opera proportions they have. Here it can also be said that sound cost planning principles, validly applied, would have alerted policy makers to the perennial trap situation which has resulted in the owner of a building or other structure becoming committed to a project whose final cost grossly exceeds the estimates made and accepted in good faith when the decision to build was taken.

The critical conservation of limited and irreplaceable natural resources such as materials, energy and water could have been effected infinitely more successfully had available knowledge and technology been exploited. Good examples here are the use of solar energy, especial- ly for domestic, institutional and industrial purposes, and the use of toilet cisterns which would reduce the amount of water consumed for this purpose to less than half the present figure.

Quite apart from the serious and adverse consequences of resistance to innovation in the technical and management context already referred to, there is a far more im portant effect of an apparent lack of understanding on the part of the policy makers of a need for innovative thinking and action in dealing with two related problems, namely instability in the building and construction industries, and inflation. While these matters are frequently and glibly discussed, and while fully appreciating their complexity and intractability, it is to me inexplicable that so little has been done to deal with them.

\section{Action to facilitate the application of innovations}

While some basis for action to overcome barriers to innovation is implicit in what has been said, it may be useful to attempt to crystallize these in five broad fields, namely management, training and education, better communication, legislation and research and development.

\section{Management}

In general terms management can do a great deal to encourage innovation; more specifically:

- it can encourage the generation of new technology and techniques by supporting research, both domestically and in bodies such as universities and research institutions;

- it can develop in-house a mechanism for evaluating and procuring, modifying and adapting novel technology;

- it can take steps to familiarize and train its staff in all aspects of innovation and then apply it in practice;

- it should develop and implement procedures for the effective monitoring of and feedback on the use of innovations with a view to corrective action and improving their application.

\section{Training and Education}

Systematic and suitably oriented training and education, specifically aimed at acquainting all concerned with the potential and limitations of innovation, and how to select and apply it in practice, is badly needed. Such training should:

- proceed at all levels from professional designer to operative, and in such a way as to be intelligible and meaningful to the trainee;

- be completely objective, balanced and critical in the sense that the trainee neither becomes obsessional about the advantages of innovation, nor so aware of possible problems that he is scared off;

- be ongoing and continuous. All too often a person, having obtained a qualification, closes his mind to further improving himself; thus properly structured formal ongoing education of the refresher type with the emphasis on novel developments is essential;

- be worthwhile for the recipient in the sense that the value of such knowledge should be suitably recognized in terms of advancement or improved remuneration. 


\section{Better Communication}

Better communication, which in a sense is education, is also essential if innovation is going to be validly implemented. We need to improve communication:

- on the building site between those who instruct and supervise and those who actually do;

- on an interdisciplinary basis, particularly during the design stage to ensure that the possible problems implicit in the use of an innovation as well as its advantages are fully taken into account;

- within a firm to make sure that its use is being optimized and that the left hand knows what the right hand is doing;

- between the public and private sectors to ensure that an innovation is acceptable before too much effort is expended on it. This is especially true of novel contractual procedures;

- between those developing innovations, such as research organizations or the manufacturer or promotor of an innovation and those actually using it. This is particularly important if for instance the use of a new material requires radically different storage or application procedures;

- on the international level, since in activities such as building and construction which tend to be more isolationistic internationally than for instance highly sophisticated technology intensive industries, such as electronics or pharmaceuticals, it often takes years rather than weeks before a new development becomes known and is applied.

\section{Legislation}

Largely because its implementation is assured by the force of law, legislation such as building regulations is extremely important in the application of innovation. Important matters here are:

- that those framing legislation are fully aware of the economic, technical and management implications of what passes into law;

- the need for legislation to be regularly updated so as to take new developments into account;

- for legislation to be explicit, unequivocal, and expressed in terms which are fully understandable both to those who are required to administer it and to those who are required to obey it;
- that legislation allow the maximum discretion compatible with achieving its objectives, and the competence and judgement of those applying it;

- that those interpreting and administering legislation are well trained and kept fully up to date with technology and changed legal requirements and procedures.

\section{Research and Development}

Research and development are the life blood of innovation and, if they are to serve the needs of the building and construction communities; they must:

- be planned, carried out and applied in close collaboration with the end users, namely those who manufacture prescribe and apply innovation;

- be practical and economic in their use, and fully take into account the conditions under which they will be used and the people using them;

- be made known to those who can apply them as soon as possible.

The people involved in research and development must be prepared to advise on the use of new developments, and accept and promote feedback to either improve the effectiveness of their innovations, or solve problems associated with their use.

\section{Conclusion}

In conclusion I would like to make three final statements:

- While there certainly is a need for penetrating and broad thinking, add the thought that the use of innovation requires not only lateral thinking, but that such lateral thinking often has to extend around corners, sometimes in three dimensions.

- The effective use of innovations is in itself dependent on the rediscovery and application of three human qualities which are sadly becoming obsolete, namely the work ethic, complete and absolute personal integrity, and acceptance of the principle that much of the reward of a professional lies in job pride and satisfaction.

- The fullest possible rational use of innovations within the framework of sound engineering principles, is a vitally important objective if mankind in general, and Southern Africa in particular, is to achieve the socio-economic goals after which all thinking people strive. 